\title{
THE PRECISION OF ROD-ROW TESTS WITH WHEAT AS INFLUENCED BY ALLEVIATING A PHOSPHORUS DEFICIENCY
}

\author{
A. A. Guitard ${ }^{1}$ \\ Canada Department of Agriculture, Beaveriodge, Alberta \\ [Received for publication January 7, 1960]
}

\begin{abstract}
At Beaverlodge, during 1950 to 1952 , inclusive, the application of 50 pounds per acre of ammonium phosphate (11-48-0) to 25 wheat varieties in rod-row tests reduced the average number of days from seeding to heading and to ripening, and increased the yield, height and kernel weight. During some years there were variety $\mathrm{x}$ fertilized interactions for days to head and ripen, and for kernel weight.

The fertilizer also increased the precision of the tests for yield, height and kernel weight but did not infuence the precision for days to ripen and reduced the precision for days to head. Phosphate fertilization would appear to increase the precision by reducing the influence of soil variability.
\end{abstract}

\section{INTRODUCTION}

In much of the Upper Peace River region cereal crops grown on visibly uniform areas of soil show large localized variations in plant development and yield. At the Experimental Farm, Beaverlodge, Alberta, these variations are observed even within rod-row tests grown on summerfallow that has been selected and prepared to provide maximum uniformity. As cereal crops grown on summerfallow at Beaverlodge respond only to applications of phosphorus (1), experiments were conducted to determine if ammonium phosphate fertilizer would increase the uniformity of wheat variety tests.

\section{MATERIAL AND METHODS}

Three wheat varieties and twenty-two advanced generation hybrids were grown at Beaverlodge during 1950 to 1952, inclusive, in six replicate, balanced lattice, split plot, rod-row tests. Each eight-row variety plot had four rows seeded without fertilizer and four with ammonium phosphate (11-48-0) applied with the seed at the rate of 50 pounds per acre. The tests were grown on visibly uniform soil that had been summerfallowed for 2 years. Yield in bushels per acre, number of days to head and to ripen, height in inches, and weight per 1000 kernels in grams were recorded for each sub-plot.

The tests were analysed assuming a randomized block arrangement. A split plot analysis was applied to each test to determine the significance of the response to fertilizer and of the variety $x$ fertilizer interaction. The fertilized and unfertilized sub-plots were also analysed as independent tests and the respective coefficients of variation calculated. For yield, both the randomized block and balanced lattice analyses were used to determine the relative efficiency of the two designs.

\section{RESULTS AND DISCUSSION}

The mean responses for the unfertilized and fertilized tests, presented in Table 1, show that the application of ammonium phosphate reduced the average number of days to head and to ripen, and increased the yield, height and kernel weight of the wheat varieties. Although there were distinct differences in growing conditions, the same trends in response to phosphate fertilization were recorded during the 3 years, with the exception of kernel weight in 1952.

ICerealist, Experimental Farm, Beaverlodge, Alta. 
Table 1. - MEAN Response of Wheat Varieties SEeded Without Fertilizer and With AMMONIUM PHOSPHATE $(11-48-0)$ AT 50 POUNDS PER ACRE

\begin{tabular}{|c|c|c|c|c|c|c|}
\hline Year & $\begin{array}{l}\text { Fertilizer } \\
\text { treatment }\end{array}$ & $\begin{array}{l}\text { Yield in } \\
\text { bu./ac. }\end{array}$ & $\begin{array}{l}\text { Days to } \\
\text { head }\end{array}$ & $\begin{array}{l}\text { Days to } \\
\text { ripen }\end{array}$ & $\begin{array}{l}\text { Height } \\
\text { in inches }\end{array}$ & $\begin{array}{l}\text { Weight } \\
\text { per } 1000 \\
\text { kernels } \\
\text { in grams }\end{array}$ \\
\hline 1950 & $\underset{11-48-0}{\text { Nil }}$ & $\begin{array}{r}5.6 \\
12.0\end{array}$ & $\begin{array}{l}59.6 \\
56.7\end{array}$ & $\begin{array}{l}115.3 \\
112.9\end{array}$ & $\begin{array}{l}22.2 \\
23.9\end{array}$ & $\begin{array}{l}21.2 \\
25.7\end{array}$ \\
\hline 1951 & $\underset{11-48-0}{\text { Nil }}$ & $\begin{array}{l}42.1 \\
61.2\end{array}$ & $\begin{array}{l}60.6 \\
58.2\end{array}$ & - & $\begin{array}{l}36.2 \\
37.8\end{array}$ & $\begin{array}{l}32.5 \\
34.0\end{array}$ \\
\hline 1952 & $\begin{array}{c}\mathrm{Nil} \\
11-48-0\end{array}$ & $\begin{array}{l}41.5 \\
49.5\end{array}$ & $\begin{array}{l}69.1 \\
68.2\end{array}$ & $\begin{array}{l}127.7 \\
126.1\end{array}$ & $\begin{array}{l}31.3 \\
31.6\end{array}$ & $\begin{array}{l}35.4 \\
34.8\end{array}$ \\
\hline Av. & $\underset{11-48-0}{\mathrm{Nil}}$ & $\begin{array}{l}29.7 \\
40.9\end{array}$ & $\begin{array}{l}63.1 \\
61.0\end{array}$ & $\begin{array}{l}121.5 \\
119.5\end{array}$ & $\begin{array}{l}29.9 \\
31.1\end{array}$ & $\begin{array}{l}29.7 \\
31.5\end{array}$ \\
\hline \multicolumn{2}{|c|}{$\begin{array}{l}\text { Per cent increase } \\
\text { in average response } \\
\text { attributed to } \\
11-48-0\end{array}$} & 37.7 & -3.3 & -1.6 & 4.0 & 6.1 \\
\hline
\end{tabular}

Note: All treatment differences exceed the 1 per cent level of probability.

TABLE 2. - COEFFicieNtS OF VARIATION IN PER CENT FOR WHEAT TESTS SEEdED Without FERTILIZER AND WITH AMMONIUM PHOSPHATE (11-48-0) AT 50 POUNDS PER ACRE

\begin{tabular}{|c|c|c|c|c|c|c|c|}
\hline \multirow{2}{*}{ Year } & \multirow{2}{*}{$\begin{array}{l}\text { Fertilizer } \\
\text { treatment }\end{array}$} & \multicolumn{2}{|c|}{ Yield in bu./ac. } & \multirow{2}{*}{$\begin{array}{l}\text { Days } \\
\text { to } \\
\text { head }\end{array}$} & \multirow{2}{*}{$\begin{array}{l}\text { Days } \\
\text { to } \\
\text { ripen }\end{array}$} & \multirow{2}{*}{$\begin{array}{l}\text { Height } \\
\text { in } \\
\text { inches }\end{array}$} & \multirow{2}{*}{$\begin{array}{l}\text { Weight } \\
\text { per } 1000 \\
\text { kernels } \\
\text { in grams }\end{array}$} \\
\hline & & $\begin{array}{l}\text { Random- } \\
\text { ized } \\
\text { block }\end{array}$ & $\begin{array}{l}\text { Balanced } \\
\text { lattice }\end{array}$ & & & & \\
\hline 1950 & $\underset{11-48-0}{N i l}$ & $\begin{array}{l}34.39 \\
22.01\end{array}$ & $\begin{array}{l}30.94 \\
17.88\end{array}$ & $\begin{array}{l}2.29 \\
2.34\end{array}$ & $\begin{array}{l}1.50 \\
1.44\end{array}$ & $\begin{array}{r}15.77 \\
9.22\end{array}$ & $\begin{array}{l}7.80 \\
6.92\end{array}$ \\
\hline 1951 & $\underset{11-48-0}{\text { Nil }}$ & $\begin{array}{l}27.53 \\
12.59\end{array}$ & $\begin{array}{l}19.16 \\
10.28\end{array}$ & $\begin{array}{l}1.53 \\
2.14\end{array}$ & - & $\begin{array}{l}6.32 \\
4.53\end{array}$ & $\begin{array}{l}6.06 \\
4.88\end{array}$ \\
\hline 1952 & $\underset{11-48-0}{\text { Nil }}$ & $\begin{array}{l}8.51 \\
8.78\end{array}$ & $\begin{array}{l}8.33 \\
8.30\end{array}$ & $\begin{array}{l}0.79 \\
1.00\end{array}$ & $\begin{array}{l}1.11 \\
1.15\end{array}$ & $\begin{array}{l}4.54 \\
4.50\end{array}$ & $\begin{array}{l}2.53 \\
2.25\end{array}$ \\
\hline Av. & $\underset{11-48-0}{\mathrm{Nil}}$ & $\begin{array}{l}23.48 \\
14.46\end{array}$ & $\begin{array}{l}19.48 \\
12.15\end{array}$ & $\begin{array}{r}1.54 \\
11.83\end{array}$ & $\begin{array}{l}1.30 \\
1.30\end{array}$ & $\begin{array}{l}8.88 \\
6.08\end{array}$ & $\begin{array}{l}5.46 \\
4.68\end{array}$ \\
\hline \multicolumn{2}{|c|}{$\begin{array}{l}\text { Per cent gain in } \\
\text { average precision } \\
\text { caused by 11-48-0 }\end{array}$} & 62.4 & 60.3 & -15.8 & 0.00 & 46.0 & 16.7 \\
\hline
\end{tabular}

NoTE: All factors analysed as randomized block design, except yield which was analysed as both randomized block and balanced lattice design

There were significant variety $\mathrm{x}$ fertilizer interactions only for days to head and days to ripen in 1952 and for weight per 1000 kernels in 1950 and 1952. This general stability of varietal response to phosphate fertilization agrees with the work of Reitz and Myers (2) which indicated that wheat varieties of similar adaptation tend to respond in the same way to applications of superphosphate. 
The coefficients of variation, presented in Table 2, show that phosphate fertilization also increased the precision of the tests for all characteristics except days to head and to ripen. The large increases in precision during 1950 and 1951 for the fertilized tests undoubtedly result from a reduction in soil variability. The manner in which phosphate fertilization reduces variability warrants further investigation.

The low coefficients of variation for the unfertilized test in 1952 indicate greater basic uniformity of plant development than during the other 2 years. As indicated in Table 1, this could have been caused by a less critical phosphorus deficiency. More favourable temperature and moisture conditions during the growing season may have contributed also to this response.

The application of ammonium phosphate caused average increases in precision for yield of 62.4 per cent based on the randomized block and 60.3 per cent based on the balanced lattice design. The similarity of these increases in precision suggests that much of the variability in the unfertilized tests was caused by numerous, localized, randomly distributed soil variations.

Ammonium phosphate also increased the precision of the height and kernel weight determinations but had no influence on the uniformity of ripening. The decreases in precision for days to head may be attributed to an observed increase in tillering which prolonged the heading period of each plot.

\section{CONCLUSIONS}

At Beaverlodge the growth of wheat on summerfallow is restricted by a deficiency of available phosphorus in the soil. Associated, localized, randomly distributed soil variations detract from varietal comparisons in rod-row tests. The test precision can be increased appreciably for yield, height and kernel weight by applying ammonium phosphate (11-48-0) with the seed at a rate of 50 pounds per acre.

All cereal crops on summerfallow in the Upper Peace River region respond to phosphate fertilization, and unfertilized rod-row tests normally show extreme variability. Thus, it is assumed that the precision of most, if not all, cereal tests in the region can be increased by applying a phosphatic fertilizer at the time of seeding. It is also probable that in many other regions the precision of cereal tests can be increased by correcting existing soil nutrient deficiencies.

\section{REFERENCES}

1. Anderson, C. H., and E. C. Stacey. Soil management practices in the Upper Peace River region. Can. Dept. Agr. Publ. 985. 1956.

2. Reitz, L. P., and H. E. Myers. Response of wheat varieties to applications of superphosphate. J. Amer. Soc. Agron. 36:929-936. 1944. 